\title{
居場所の制度化と建築計画学における事例研究 INSTITUTIONALIZATION OF IBASHO AND CASE STUDIES IN ARCHITECTURAL PLANNING RESEARCH
}

\author{
田中康 裕*1
}

\section{Yasuhiro TANAKA}

\begin{abstract}
"Ibasho" was originally used to describe non-institutional places. Afterward, some places with keywords such as ibasho were institutionalized. However, a question arises as to how ibasho, that is, non-institutional places, can be institutionalized. Therefore, this paper discusses the institutionalization process of ibasho and case studies in architectural planning research involved in this process. It is possible to consider the institutionalization of ibasho from the perspective of the inversion of "demand-function" relationship. This paper found that focusing on scarcities, considering places studied as means to fill the scarcities, and that generalizing research findings, lead to the inversion of "demand-function" relationship.
\end{abstract}

Keywords : Ibasho, Institution, Institutionalization, “Demand-Function” Relationship, Architectural Planning Research, Case Study 居場所, 制度・施設, 制度化, 「要求一機能」関係, 建築計画学, 事例研究

\section{1. 研究の背景と目的}

本稿は居場所の制度化に注目し、これがどのようなプロセスなの か、そして、建築計画学における事例研究はこのプロセスにどのよ うに関わっているかを考察することを目的とする。

居場所は 1980 年頃から制度・施設洼1)でないものとして注目さ れ始め、その後、制度・施設の枠組みでは十分に対応できない課題 に直面した人々により開か水、運営される場所におけるキーワード になってきた。それと同時に、宅老所を制度化した小規模多機能型 居宅介護、コミュニティカフェなぞを制度に取り込んだ通いの場の ように、居場所が制度・施設に取り込まれる動きも生じてきた。本 稿ではこの動きを居場所の制度化と捉えているが、ここで疑問が生 じる。制度・施設ではない居場所が制度化されるとは、そもそもど のようなプロセスなのかという疑問である。

居場所の制度化に対しては、居場所が目指していたものを広く普 及させることが可能になるという見方がなされる一方で、居場所が 目指していたものが変質したり、多梯な可能性が損なわれたりする という意見もみられる。居場所の制度化について、その是非を含め て議論を深めるためには、議論の下地として居場所の制度化がぞの ようなプロセスかを考察する必要がある。

建築計画学のみによって居場所の制度化が進めら机たとは言元 ないが、「建築計画の調査研究成果は、いわゆる建築計画における 『型』として、モデルプランや標準設計あるいは行政の指針や法令 といった形で社会制度の中に取り込まれた。このような発展の傾向 は、建築計画に関与した多くの先達が好んで意図したわけでなく、 逆に慎重な意見を常に述べていた」 ${ }^{2}$ 、「個室化・ユニットケアの 流机」に代表されるように「先駆的な試みを研究で取り上げそ扎が 制度化さ水普遍化していくこともある」ろ) と指摘されているように、 建筑計画学における事例研究の成果が制度に取り込まれる傾向を有 するとすれば、居場所を研究対象としてきた建築計画学が、居場所 の制度化と無関係であるとも言えない。本稿は、建築計画学の成果
が制度に取り込まれる現象を、居場所の制度化という具体例を通し て考察するものとして位置づけられる。

本稿の考察の対象は『日本建築学会計画系論文集』に揭載され た論文のうち、タイトルに居場所を含む論文である。これらの論文 は必ずしも制度・施設ではない場所を調査対象としているわけでな く、施設を調查対象とする論文、つまり、居場所を制度・施設との 関わりで捉えている論文も多い。ただし、居場所そのものではな く、居場所の制度化に対する建築計画学の関わりを考察するために は、施設を調査対象とする論文も含めた考察が必要だと考えた。本 稿は、考察の対象としている論文が居場所の制度化を進めることを 意図したと考えるものではないが、「建築計画に関与した多くの先 達が好んで意図したわけでなく」と指摘されていたように、研究者 の意図に関わらず建築計画学の成果が制度に取り込まれる傾向があ るとすれば、研究者の意図と切り離した考察が必要である。

本稿で注目するのは、事例研究における議論の内容ではなく論 点である。ここでいう論点とは行動観察調查、アンケート調査、ヒ アリング調查なぞの調査方法だけでなく、どのような問題意識や目 的で研究が行われているか、どのように調査対象が選ばれ、ぞのよ うに議論が展開されているかなどを含むものである。特に本稿では 問題意識と目的を考察の手がかりとする。問題意識や目的は明確な 方法として一般に確立されているわけでなく、それぞれの研究者に よって定められるものである。それにも関わらず何らかの共通を見 出すことができるとすれば、そこに個々の研究者の意図を越えた建 築計画学における事例研究の特徵が現れていると考元る。

\section{2. 研究の方法}

本稿は『日本建築学会計画系論文集』に揭載された論文のうち、 (1)夕イトルに居場所を含む、(2)国内の事例を対象としている、(3)実 験調査でないという3つの条件を満たす 31 編（以下、建築計画学

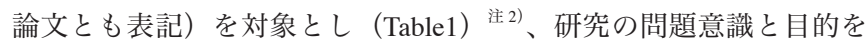


手がかりとして、その論点を論文のテキストから読み取っていく。 以下では対象とする論文を(1)〜31)の番号で表記することとする。

31 編の中で最も早い論文の刊行年は 1997 年であり、その後、継 続的に刊行されている。特に 2000 年代は刊行数が多く、2006 年と 2008 年にはそれぞれ 4 編が刊行されている。

\section{3. 居場所の制度化}

\section{3-1. 居場所}

居場所は、元々は物理的な位置を意味する語だったが、1980 年 代に入ってから「学校に行かない・行けない子どもたち」との関 わりで使われるようになる。1980 年代半ば、『居場所』と言えば、 学校に行けない子どもたちのフリースペースやフリースクールをさ していた」4)、「人間関係が学校に集中する中で、学校に身の置き ぞころのない児童生徒」にとっては「何よりもまず本人の存在が認 められる空間や人間関係が必要とされたのである。それは、居場所 としか呼ぶほかないものだった」5) と指摘されているように、当時、 居場所は学校という制度・施設ではないものであった。

この後、居場所がキーワードになる様々な場所が同時多発的に開 かれてきた。1995 年頃からは宅老所が開かれ始める ${ }^{6)} 。 1997$ 年に は最初の地域の茶の間である「地域の茶の間・山二ッ」が開かれて いる。2000 年頃からは各地にコミュニティカフェが開かれるよう
になった ${ }^{7)}$ 。こども食堂の名称が最初に使われたのは 2012 年であ $3^{8)}$ 。いずれも、制度・施設の枠組みでは十分に対応できない課題 に直面した人々により開かれ、運営されてきた場所である。

\section{3-2. 居場所の制度化}

居場所の制度化は、次のような領域においてみることができる。 子どもの居場所に関しては、1992 年に文部省委嘱の学校不適応 対策調査研究協力者会議がまとめた最終報告書「登校拒否 (不登校) 問題について：児童生徒の『心の居場所』づくりを目指して」注3) において、登校拒否はどの子どもにも起こりうるという観点にたっ て、学校が子どもにとって自己の存在感を実感でき精神的に安心で きる場所（心の居場所）となることが大切であると指摘された」9)。 2004 年度からは文部科学省による「子どもの居場所づくり 新プラ ン」が始まり、具体的な取り組みとして「地域子ども教室」が始め られた。2007 年度には文部科学省と厚生労働省の共同事業である 「放課後子どもプラン」により、放課後子ども教室」が始められた。 2つの子ども教室の違いについて、「地域子ぞも教室」の活動場所 は「各受託団体にゆだねられて」いたのに対して、「放課後子ども 教室」の活動場所はできる限り小学校内で実施する方向性が打ち出 されたことで、「放課後子ども教室」は「子どもにすれば、大人と 学校の教育的視線の中で再び学校空間に囲い込まれていくことを意 味していた」と指摘されているように ${ }^{4)}$ 、子どもの居場所をめぐる

Table 1 List of papers to be discussed in this paper（本稿で考察の対象とする論文一覧）

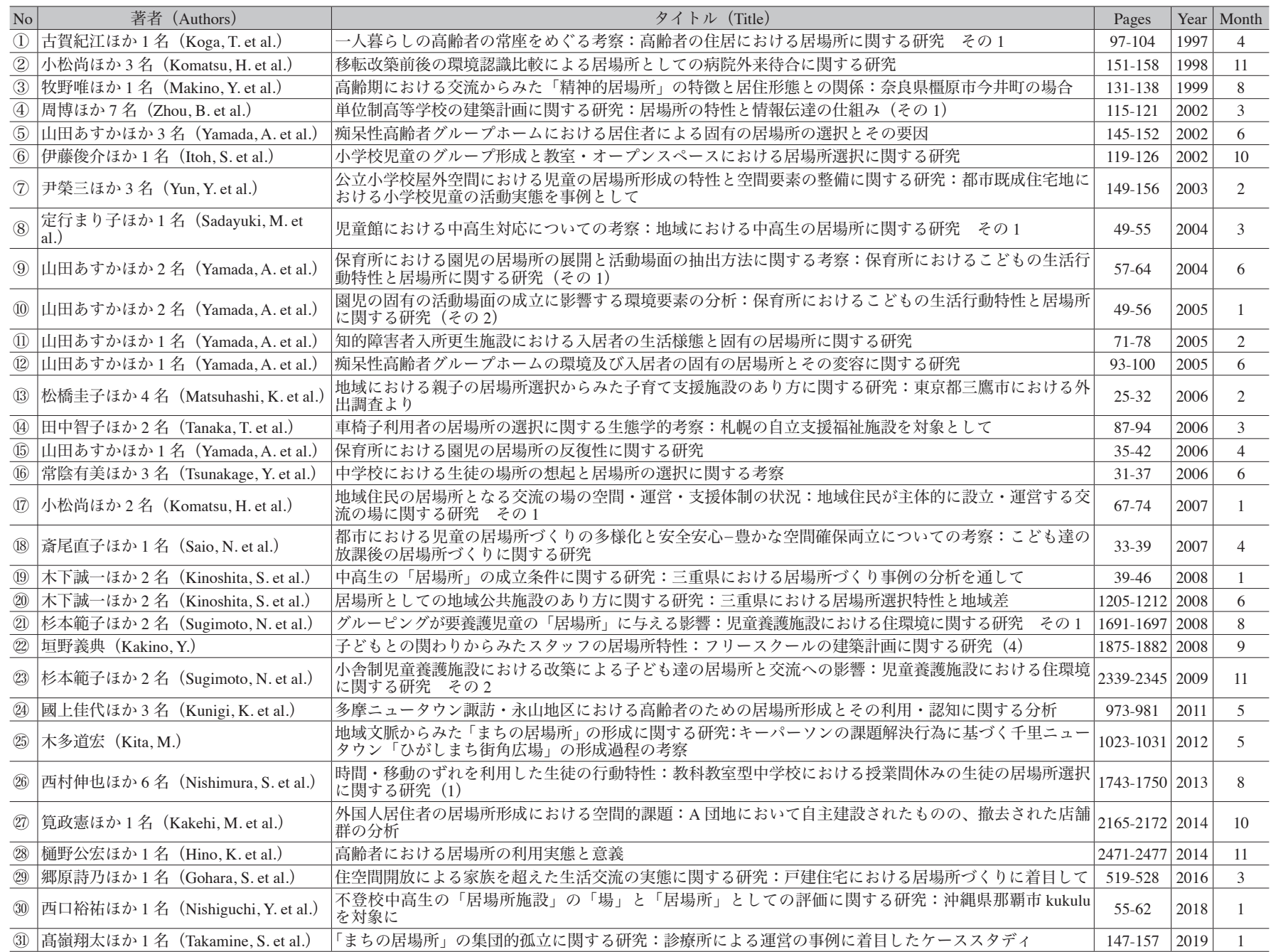


施策は、子どもを「再び学校空間に囲い込」んでいく傾向を有する ものに変質していったのである。

小規模多機能型居宅介護、通いの場は高齢者との関わりで居場所 が制度化されたものである。介護保険法改正により 2006 年に制度 化された小規模多機能型居宅介護は、「宅老所が行ってきた活動を もとに、その『地域密着』『小規模』『多機能』という形態をモデル として、介護保険のなかで制度化されたもの」 ${ }^{6)}$ と指摘されている 通り、宅老所が制度化されたものである。2015 年から始まった介 護予防・日常生活支援総合事業（新しい総合事業）に盛り込まれた 通いの場は、「『介護予防・日常生活支援総合事業』…‥のない、
『居場所・サロン』の取り組み（サービス）が盛り込まれています。 新しい総合事業では、これを『通いの場』と呼んでいます」10) と 指摘されている通り、コミュニティカフェ、地域の茶の間などを制 度に取り込んだものである。宅老所、コミュニティカフエ、地域の 茶の間は多様な属性の人々に開かれた場所だつたが、介護保険や介 護予防との関わりで制度化された小規模多機能型居宅介護、通いの 場は高齢者との結びつきが強くなっている。こうした動きにより居 場所の目的も「介護予防・健康寿命延伸のため」と紹介されるよう になってきたが、自らは居場所を「日々の生きる喜びや楽しみ、自 己実現の場であり、結果、地域に生きる安心につながることを願つ

Table 2 Outline of the papers to be discussed in this paper（本稿で考察の対象とする論文の概要）

\begin{tabular}{|c|c|c|c|c|}
\hline No & $\begin{array}{c}\text { 調査対象 } \\
\text { (Research objects) }\end{array}$ & $\begin{array}{c}\text { 調査対象者の主な属性 } \\
\text { (Main attributes of the research } \\
\text { subjects) }\end{array}$ & $\begin{array}{c}\text { 居場所の定義 } \\
\text { (Definition of "Ibasho"） }\end{array}$ & $\begin{array}{l}\text { 調査タイプ } \\
\text { (Research } \\
\text { Type) }\end{array}$ \\
\hline (1) & 「住居」 & ○「一人暮らしの高齢者」 & - & 少数精密 \\
\hline (2) & $\begin{array}{l}\text { 病院の「待合を中心としたコ } \\
\text { モンスペース」 }\end{array}$ & ○「外来患者」 & - & 少数精密 \\
\hline (3) & 「重要伝統的建造物群保存地区」 & ○「高歯者」 & 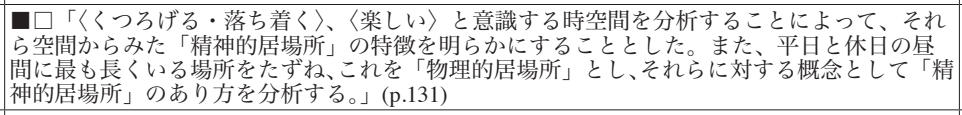 & 大量統計 \\
\hline (4) & ○「単位制高等学校」 & ○「生徒」 & $\begin{array}{l}\text { 口「居場所は人がいる場所と示す。本研究では、アンケート調査から生徒がよく利用する学 } \\
\text { 校内の共用スペースが苦場所と定義されている。」(p.121) }\end{array}$ & 少数精密 \\
\hline (5) & ○「痴呆性高㱓者グループホー & 「痴呆性高歯者」 & $\begin{array}{l}\text { 口「ここでいう居場所とは、単に壁や床などの建築的要素や家具などのしつらえのみならず、 } \\
\text { 他者の存在などの周囲の状況や、居住者の生活背景、現在の生活の文脈や本人の思い入れなど、 } \\
\text { 人的・心理的要素をも含む概念とする。」(p.146) }\end{array}$ & 少数精密 \\
\hline (6) & ○「学校」 & ○「学校児童」 & - & 少数精密 \\
\hline (7) & ○「小学校屋外空間」 & ○「児童」 & - & 少数精密 \\
\hline (8) & 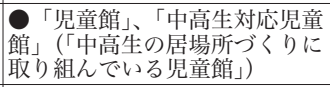 & 「児童館」の設置・運営者 & $\begin{array}{l}\text { 口「「居場所」とは、自らをありのままに受け入れてもらえる場と解釈することができ、そこ } \\
\text { にいて古心地が良いところを意味している。さらに、単なる物理的な空間のみならず、心理 } \\
\text { 的な安心感を得られる空間を。」(p.49) }\end{array}$ & $\begin{array}{l}\text { 少数精密 } \\
\text { 大量統計 }\end{array}$ \\
\hline (9) & ○保育所」 & ○「園児」 & 口「こどもたちの活動が展開している場所（以下：居場所）の分析を通じて、…・」(p.58) & 少数精密 \\
\hline (10) & ○保育所」 & ○「園児」 & 口「こどもたちの活動が展開している場所（以下:居場所）を分析することで、….」(p.49) & 少数精密 \\
\hline (11) & 「知的障害者入所更生施設」 & $\bigcirc\ulcorner$ 知的障害者」 & $\begin{array}{l}\text { 口「滞在頻度・時間の合計が他の場所に比べて特に多い・長い場所を各入居者ごとに認定し、固 } \\
\text { 有の居場所」として抽出した。」(p.75) }\end{array}$ & 少数精密 \\
\hline (12) & $\begin{array}{l}\text { ○「痴呆性高歯者グループホー } \\
\text { ム」 }\end{array}$ & ○痴呆性高齢者」 & $\begin{array}{l}\text { 口「ここでいう居場所とは、壁や床、家具などの物理的要素、職員や他の入居者の人的要素、 } \\
\text { 入居者の生活背景、現在の生活の文脈や本人の思い入れなどの個人的要素を含む概念である。」 } \\
\text { (p.93) }\end{array}$ & 少数精密 \\
\hline (13) & ○子育て支援施設」 & $\begin{array}{l}\bigcirc 「 4 \text { 歳未満の子どもを持つ } \\
\text { 保護者 (親子)」 }\end{array}$ & - & 大量統計 \\
\hline (14) & ○「自立支援福祉施設」 & ○「車椅子利用者」 & - & 少数精密 \\
\hline (15) & 「保育所」 & ○「園児」 & 口「保育所において園児が活動している場所（以下：居場所）と、…」」(p.35) & 少数精密 \\
\hline (16) & 「中学校」 & ○「生徒」 & - & 少数精密 \\
\hline (17) & 「交流の場」 & 「交流の場」の設立・運営者 & - & 大量統計 \\
\hline (18) & り」児童の放課後の居場所づく & $\begin{array}{l}\text { 「運営主体・現場スタッフ」「小 } \\
\text { 学校 } 1 \text { 年の児童の保護者」、 } \\
0 \text { 「小学校 } 1 \sim 3 \text { 年の児童」 }\end{array}$ & - & 少数精密 \\
\hline (19) & $\begin{array}{l}\text { ○「公共及び民間施設を利用し } \\
\text { た中高生の「居場所」」 }\end{array}$ & $\begin{array}{l}\text { 「運営者」、○「中学生及び高 } \\
\text { 校生」 }\end{array}$ & 口「本稿における居場所とは、中高生が「居られる場所」と定義する。」(p.46) & 大量統計 \\
\hline (20) & ○「地域の公共施設」 & $「 15$ 歳以上の地域住民」 & 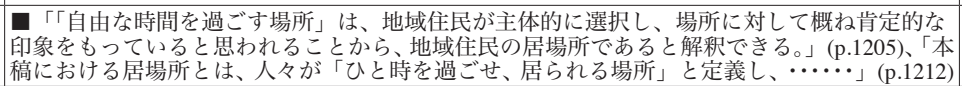 & 大量統計 \\
\hline (21) & 「児童養護施設」 & ○「要養護児童」 & 口「子どもたちに「居場所 (好きな場所・いたい場所に言い換えて質問した)」を……1p.1693) & 少数精密 \\
\hline (22) & ○「フリースクール」 & 「フリースクールのスタッフ」 & - & 少数精密 \\
\hline (23) & 〔「小舍制児童養護施設」 & ○「子ども」 & 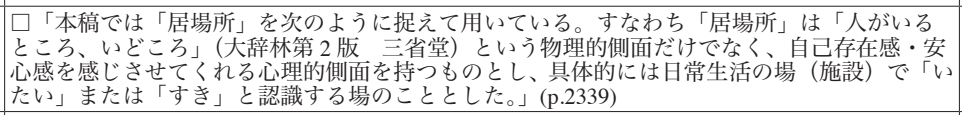 & 少数精密 \\
\hline (24) & 「高歯者の居場所」 & $\begin{array}{l}\text { ○高齢者の居場所」の利用者、 } \\
\text { 「60 歳以上の居住者」 }\end{array}$ & $\begin{array}{l}\text { 「本論で言う「高齢者の居場所」とは、行政やNPO、ボランティア団体などが開設し、高龄者 } \\
\text { に生涯学習・趣味活動、食事・喫茶、交流・情報交換などの機会と場を提供する場所を指す } \\
\text { こととする。(p.974) }\end{array}$ & 大量統計 \\
\hline (25) & 「まちの居場所」 & 「キーパーソン」 & $\begin{array}{l}\text { 口「本研究における「居場所」とは、…‥自分あるいは自分たちの意志で、特別な許可 } \\
\text { も必要とせず、思い思いに一時を過ごすことのできる場所」とする。」( } 1031)\end{array}$ & 少数精密 \\
\hline (26) & ○「教科教室型中学校」 & ○「生徒」 & - & 少数精密 \\
\hline (27) & $\begin{array}{l}\text { 「団地内の囲い地及び店舗群」 } \\
\text { (「外国人居住者の居場所」) }\end{array}$ & 「店舗群の関係者」 & $\begin{array}{l}\square 「 \text { 外国人居住者の精神的な拠り所＝居場所（以下、居場所）となる可能性があると考えら } \\
\text { 和る。」(p.2165) }\end{array}$ & 少数精密 \\
\hline (28) & 「高齢者の居場所」 & $\bigcirc\ulcorner 65$ 歳から 79 歳の高齢者」 & $\begin{array}{l}\text { 口「アンケート調查では「特に予定の無い時でも気軽に足を運べる場所」という幅広の表現 } \\
\text { を用いた（以下〈居場所〉と表記)。」(p.2472) }\end{array}$ & 大量統計 \\
\hline (29) & $\begin{array}{l}\text { 「他者に開いた交流空間」(「戸 } \\
\text { 建住宅における居場所づくり」) }\end{array}$ & $\begin{array}{l}\text { ○「開設者」(女性の高齢者)、 } \\
\text { 「利用者」 }\end{array}$ & - & 少数精密 \\
\hline (30) & 設」」不登校中高生の「居場所施 & ○「不登校中高生」 & 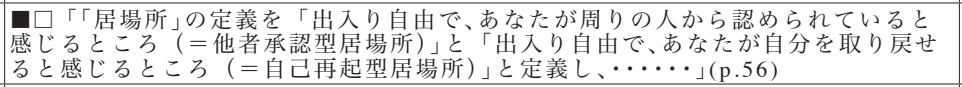 & 少数精密 \\
\hline (31) & $\begin{array}{l}\text { 「診療所によって運営されてい } \\
\text { るまちの居場所」」 }\end{array}$ & $\begin{array}{l}\text { ○「利用者」(「孤立状態にあ } \\
\text { る人々」) }\end{array}$ & $\begin{array}{l}\text { 「まちの居場所」は「柔軟な運営によって喫茶、趣味の教室、展示をはじめとした多様な活動 } \\
\text { を実施することが可能な場所である。」(p.147) }\end{array}$ & 少数精密 \\
\hline
\end{tabular}

※のは調查対象が施設であること、○は主な調查対象者が社会的弱者であることを表す。ロは行為の側面からの定義、 $\square は$ 精神的・心理的側面からの定義であることを表す。 
て」運営していると話す運営者もいる ${ }^{11)}$ 。

近年、各地に開かれているこども食堂は、子どもの貧困対策とし て制度との結びつきを強めていった。こども食堂の名称を最初に使 い始めた「気まぐれ八百屋だんだん」では「こども食堂とは、子ど もが一人でも安心して来られる無料または低額の食堂」と定義され ており、「『子ども』に貧困家庭という限定はついていない」。ここ ろが、2013 年に子どもの貧困対策推進法が成立し、「こども食堂は、 学習支援 (無料塾) と並ぶ子どもの貧困対策の主要メニューとなっ ていく」ことで「ある意味では過度に子どもの貧困問題と結びつい ていった」のである。これに対して、「『こども食堂』は『こどもの 食堂』ではない。もつと多様で、雑多で、豊かなものだ」と、当初 の理念が失われることを懸念する声があげられている ${ }^{8)}$ 。

居場所の制度化に対しては、ここでみたように居場所が目指して いたものが変質したり、多様な可能性が損なわれたりするという問 題提起がなされている。

\section{3-3. 「要求一機能」関係}

佐々木嘉彦は、生活的に意味があり、かつ操作可能な「人一物」 関係を生活の最小単位として定義する。そして、「行為は欲求充足 の過程」であり、それは「生活主体がある目的（=欲求）をもって 対象（=物）に働きかけ、欲求と対応する何かを自らのなかにとり 込むことによって充足される」。ここで、「目的（=欲求、必要）を 要求と呼び、その目的達成（=欲求充足）において物がはたす（あ るいは期待されている）役割（=働き）を機能と呼べば、『人-物』 関係は、人間の行為において、『人の要求』と『物の機能』を媒介 して人と物が結びつく関係としてとらえることができる」と指摘す る。さらに、「建築計画の分野では建築の機能などというとき、住 み手の要求ときりはなしてとらえる傾向がある」が、「機能は要求 と対応する概念」であり、「物の機能は固定的であるのではなく、 要求のちがいや変化に対応して異なる」とも指摘する ${ }^{12)}$ 。

佐々木嘉彦の議論をふまえて、宅老所と施設の違いを説明するの が大原一興である。大原一興は、宅老所が「制度に乗らない新たな サービスをむしろ創出することになっている」ことに触れて、「宅 老所活動の存在意義は、提供されるサービス機能ではなく、地域の 要求を引き出すための装置として有効となる点にある」と指摘す る。一方、「高齢者施設では、機能が単独で先行し施設が建設され、 しかるのちにそれに適した居住者（例えば要介護度の高い人、認知 症の人など）が入居者として募集される」。ここでは「機能が要求 よりも先行」しており、「先に要求がありそれに対して機能が発生 する、という本来の『要求一機能』関係が倒立している」 ${ }^{13)}$ 。

以上の議論をふまえれば、居場所と施設の違いを次のように捉え ることができる。即ち、居場所では、機能は生じてくる要求にその 場所で対応することで事後的に備わってくる。それに対して施設で は、機能は要求に先行して実現すべきものとしてあらかじめ設定さ れる。「要求一機能」関係を反転させることで、制度・施設ではな い居場所を、制度・施設のモデルにしたり、制度・施設に取り込ん だりすることが可能になるのである注4)

居場所と施設では「要求一機能」関係が反転していると捉えるこ とで、居場所の制度化の考察を、「要求一機能」関係を反転させる プロセスの考察へと敷衍することができる。建築計画学における事 例研究がこの反転にどのように関わってくるかを考察することが、
本稿の以下の部分での目的となる。

\section{4. 建築計画学論文における調査対象と居場所の定義 \\ 4-1. 調査対象}

本稿が対象とする 31 編の論文のうち 22 編が施設を調査対象とし ている（Table 2)。31 編の論文の調査対象を分類するにあたっては、 「中高生の居場所づくりに取り組んでいる児童館」8、「児童の放課 後の居場所づくり」18、「公共及び民間施設を利用した中高生の『居 場所』」(19、「不登校中高生の『居場所施設』」(30)」ううに調査対象 が居場所と表現されていても、著者が調査対象を施設と捉えている 場合は、著者に従い施設を調査対象とする論文として分類した。ま た、フリースクール、痴呆性高齢者グループホームのように既存の 施設ではない場所が調査対象とされていても、「フリースクールは、 一般的には『不登校生徒の居場所』との認識が強いが、本研究で は、フリースクールを教育施設の一形態と位置づけている」(22、「痴 呆性高齢者ケアを目的とした居住施設の一形態としてグループホー ム」(5)というように注5)、著者が施設と位置づけている場合も、著 者に従い施設を調査対象とする論文として分類した。これらの例か らも、建築計画学論文においては居場所が施設との関わりをもって 捉えられていることがわかる。

主な調查対象者の属性については、31 編のうち 25 編が子ども、 高齢者、患者、障害者なぞ一般的に社会的弱者とみなされる属性の 人を対象としている。

\section{4-2. 居場所の定義}

31 編の論文うち、居場所をどのような意味で用いているかとい う定義を明記している論文は 19 編である（Table2）。19編のうち、 (24)310 2 編は居場所を制度・施設でない場所として定義している。 残りの 17 編については、13 編が「生徒がよく利用する学校内の共 用スペース」 (4)、「園児が活動している場所」(15)な゙のように行為 の側面から、6 編が「心理的な安心感を得られる空間」8、「日常 生活の場（施設）で「いたい」または「すき」と認識する場」(23な ぞのように精神的・心理的な側面から居場所を定義している注6)。

居場所を行為、及び、精神的・心理的な側面から定義している論 文の中には、何らかの状態を可能にするものとして居場所を定義し ている論文がある。具体的には、「居られる場所」(1920、「思い思い に一時を過ごすことのできる場所」(25)、特に予定の無い時でも気 軽に足を運べる場所」(28)というように何らかの行為ができる場所を 居場所と定義している 4 編と、「自らをありのままに受け入れても らえる場」 8、「心理的な安心感を得られる空間」8、「自己存在感・ 安心感を感じさせてくれる」(23、「自分を取り戻せる」(30)というよ うに何らかの精神的・心理的な状態が実現される場所を居場所と定 義している 3 編である。

先にみたように、(8)18)19(30の 4 編は調査対象が居場所と表現され ながら著者はそれを施設と捉えていたが、これらのうち(8)(19)(30) 3 編は居場所を何らかの状態を可能にするものとして定義している。

\section{5. 建築計画学論文の論点}

\section{5-1. 問題意識としての欠如への注目}

31 編のうち 20 編が、議論を展開にするにあたつて様々な課題に 注目している。特に 14 編は、論文の最初の段落で課題に言及して 
いる。注目されている課題は、「高齢者問題とともに少子化が極め て深刻な課題となっている」(13、「少子高歯化、地域社会での人間 関係の希薄化、青少年問題など様々な社会的背景」(20のように社会 において課題になっていることや、「単位制高校では、学校生活上 の基盤となっていた従来のクラスルームの設定が難しく」(4)、「国 が推し進める小規模化・ケアの個別化は容易なことではない」(23) ように特定の施設に関わる課題などである（Table 3）注7)。注目さ れている課題は、社会の状況や既往研究などをふまえて著者が望ま しいと考える状態から、何かが欠如している状態である。
これらの論文では、著者が注目している課題を既に解決している 事例、課題を解決する可能性がある事例、あるいは、課題を考察す るための事例が調査対象として選ばれている。つまり、調査対象は 著者が注目する欠如を埋める手がかりと見なされているのである。

20 編の論文の著者が、どのように欠如を埋めようとしているか

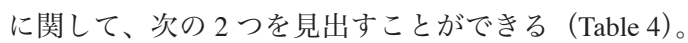

1 つは、著者が調査対象に関わる人々のニーズを把握しょうとす る場合で、「子育て支援施設』に着目しながらその利用実態と利用 者の特性やニーズを明らかにする」(13、「今後、地域全体として中

Table 3 Descriptions about issues focused on by the authors（著者が注目する課題に関する記述）

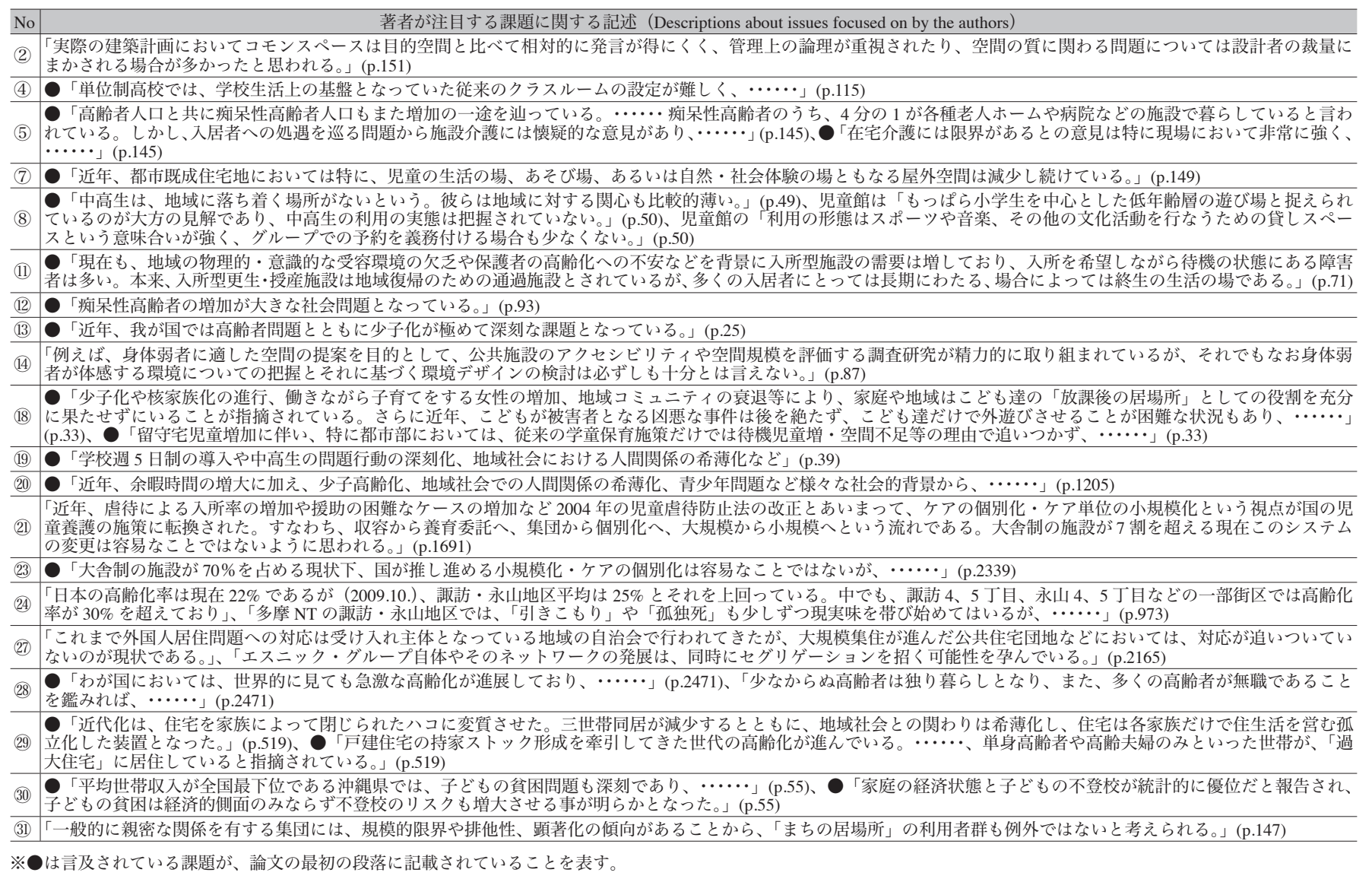

Table 4 Descriptions about grasping and suggestion of needs by the authors（ニーズの把握と提示に関する記述）

No $\quad$ ニーズの把握と提示に関する記述 (Descriptions about grasping and suggestion of needs by the authors)

(4)「生徒の居場所と情報伝達、生徒管理や帰属意識の所在などの機能を計画する必要がある。また社会人も含む、個々の生徒の学習プログラムに対応した教育と活動を支え (4) る施設の整備が必要であると考えられる。」(

(7)「学校の屋外空間は、学校教育のための空間のみならず、地域の貴重かつ安全な屋外活動拠点としてますます重要な意味を持つと考えられる。」(p.149)、小学校屋外空間に (7) は「子ども達が主体的に使いこなせるあそび場として、また、住民も共同で活用する地域の庭として機能することが求めら机ている。」(p.149)

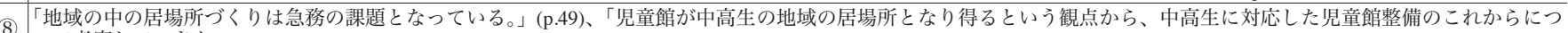
いて考察していきたい。」(p.50)

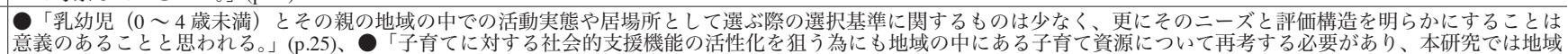

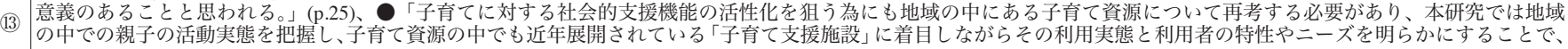
$\cdots \cdots \cdot(\mathrm{p} .25)$

18 「安全で充実した居場所づくりの早急な整備が求められる現状にある。」 $\mathrm{p}$.33)「放課後という児童にとっては長い時間帯のための空間計画」は「安全性を過度に重視する 18 ことで、こども達を管理し過ぎたり主体的な活動を阻害することなく、豊かな空間確保と空間活用を保証していくことが必要である。」(p.33)

(19) 「こうした取組みはまだ新しく、個々に試行錯誤しながら運営されているのが実情である。今後、地域全体として中高生を受け入れていくには、中高生の施設に対するニー ズを把握し、公共施設だけでなく民間施設も含めた総合的な施設整備のあり方を検討する必要があると思われる。」(p.39)

「とりわけ公共施設は、従来の施設固有の機能的サービスを中心とした観点からだけでなく、地域住民が安心して過ごせる居場所としての観点から捉え直す必要があると

(20) 思われる。」(p.1205)、・地域住民の居場所に焦点を当て、その選択場所や施設に対して抱くイメージ(施設像) から居場所に対するニーズを捉え、……」(

「身近な場所に住民同士の交流や見守りができる、身の寄せ場としての安心・安全な居場所が求められていると考える。・.....諏訪・永山地区には行政の他、特定非営 (24) 利法人 (以下:NPO)、商店街、ボランティア団体、町内会などが自律的に運営を行なっている「高歯者の居場所」が現在まで合計 10 カ所成立していることがわかっている。 こうした事実から、諏訪・永山地区は全国的にも先駆的な意味をもつモデルとなりうる存在と考える。」(p.973)

「高軨者等の活力ある暮らしや社会保障費抑制の観点から、介護予防の一層の取り組みが求められている。とりわけ、高歯者等が長時間を過ごす地域社会においては、高

(28) 齢者等の外出促進や社会的交流機会の確保のための取り組みが必要である。」(p.2471)、「多くの高齡者が無職であることを鑑みれば、サードプレイスの必要性は非高歯者 に比べて高いと言える。本研究ではこのサードプレイスに相当する場として、高㱓者の居場所を取り上げ、……」( p.2471)

※のはニーズの把握に関する記述を表す。 
高生を受け入れていくには、中高生の施設に対するニーズを把握 し」(19)ように記載されている問題意識に関わるものである。

もう1つは、論文での考察を始める前に、著者が調査対象やそこ に関わる人々に対して何らかを提示している場合で、「生徒の居場 所と情報伝達、生徒管理や帰属意識の所在などの機能を計画する必 要がある」(4)、「子ぞも達が主体的に使いこなせるあそび場として、 また、住民も共同で活用する地域の庭として機能することが求めら れている」(7)などのように記載されている問題意識に関わるもので ある。「必要がある」「求められている」という表現が典型的だが、 これらの論文の著者は調査対象やそこに関わる人々にとっての必要 なこと、つまり、ニーズをあらかじめ提示している。20 編のうち 9 編がこれに該当するが、注目すべきは、いくつかの論文では居場所 がニーズとともに言及されていることである。例えば、「安全で充 実した居場所づくりの早急な整備が求められる」18、「安心・安全 な居場所が求められている」(44などのように、著者は居場所自体を、 自らが注目する欠如を埋めるためのニーズとして、論文での考察を 始める前にあらかじめ提示しているのである。

\section{5-2. 研究目的としての知見の一般化}

研究目的としては、まず調査対象における現象の解明をあげるこ とができるが、それだけでなく、31 編のうち 19 編が「今後の単位 制高校の計画に資する」 (4)、「今後の屋外ゾーニング計画に向けた 整備要件・課題を抽出する」 (7)、「今後の高歯者の居場所づくりの ための知見を得る」(24)ように知見の一般化、つまり、調査対象に おける現象の解明を通して、一般的に適用できる知見を得ることを 研究目的としている (Table 5) 注8)。「今後の」「計画」という表現は、 研究が行われる時点では知見の適用対象がまだ存在していないこと を現す。つまり、知見の一般化を研究目的に揭げることは、知見の 適用対象がまだ存在しないことを前提とするものである。

ここで、調査のタイプを「大量統計調査」と「少数精密調査」に 分類すると、31 編のうち 23 編が「少数精密調査」 7 編が「大量統 計調査」、 1 編が両夕イプの併用となっている (Table 2) 注9)。そして、 23 編の「少数精密調査」のうち 14 編が 1 ケ所の施設や居場所のみ を調査対象としている。

研究目的と調査のタイプに注目すれば、知見の一般化を研究目 的とし、かつ、「少数精密調査」である論文は 12 編あるが、これら の論文では、それぞれにユニークである少数の調査対象から得られ た知見が、なぜ一般に適用できるのかが明確に議論されておらず、 議論の展開に飛躍がみられる。そのため 12 編の論文の中には、今 後の研究課題として他の種類を調査対象とする研究の必要性や、研 究を継続することの必要性に言及している論文がある。さらに、論 文のまと部分において、「収集できたデー夕から研究上明らかに できる内容には自ずと限界がある」(27)というようにデー夕が十分で ないことに言及している論文や、「既存施設の改変によって小規模 化する A 園の取り組みは一つのあり方として参考になるであろう」 (21)のうに断定の表現を用いてない論文もある（Table 6）注 10)。

門内輝行は「建築・都市計画の研究では、研究対象である生活と 空間が時代や社会とともに変化しており、絶えず新しい知識が求め られているため」、推論の形式として演繹だけでなく、帰納やアブ ダクション (仮説推論) が重要な役割を果たすと指摘している ${ }^{14)}$ 。 研究課題やデータが十分でないことへの言及、断定の表現を用いて
いないことは、「多くの事実から一般的な法則を導く『州納』にた いて事実がまだ十分でないこと、あるいは、「驚くべき事実から仮 説を構成する『アブダクション (仮説推論)』」において仮説の確か らしさを断定できないことを、著者自身が認識していることの現れ である。ただし、これは㷌納やアブダクションという推論の形式が 有する限界に関わることであり、本稿は帰納やアブダクションの限 界を指摘するものではない。本稿で注目したいのは、帰納やアブダ クションが有する限界を、建築計画学論文はどのように乗り越えて 知見を一般化しょうとしているかである。

\section{5-3. 知見の一般化における前提}

知見の一般化に関する飛躍を乗り越えるための前提にされてい ると捉え得ることとして、次の 2 つを見出すことができる。

1 つ目は、調査対象をある枠組みの中に位置づけることである。 知見の一般化を研究目的とする 19 編の論文について、調査対象と 知見の適用対象との関係に注目すると、「単位制高等学校」を調査 対象として「今後の単位制高校の計画に資する」(4)、监童養護施設」 を調査対象として「今後の児童養護施設の建築計画の一助となる」 (21)というように、両者が同じ枠組みの中に位置づけられている論文 がある（Table 5)。これらの論文では、調査対象と知見の適用対象 が同じ枠組みの中に位置づけられていることが、知見の一般化に関 する飛躍を乗り越える前提にされていると考えることができる。こ こでいう枠組みとは施設体系、ビルディングタイプと呼ばれるもの だが、注目すべきは施設を調査対象とする論文だけでなく、「交流 の場」を調査対象として「交流の場の空間や運営、地域の支援体制 に関する知見を得る」17、「高龄者の居場所」を調査対象として「今 後の高齢者の居場所づくりのための知見を得る」24、「外国人居住 者の居場所」を調査対象として「外国人居住者の居場所が、セグリ ゲーションを引き起こすことなく、日本人住民との相互理解を深化 させていくための要件を考察する」(27)、「診療所によって運営され ている『まちの居場所』」を調査対象として「まちの居場所」にお ける「集団的孤立の発生実態・背景を把握し、リスク想定を進める」 (31)ように、居場所を調査対象とする論文にも同様の関係がみられ ることである。「制度が機能している状況を含めて、はじめて施設 という言葉は生きている。一ヶ所しか存在しえない特殊な建物は施 設と呼ばない」 ${ }^{1)}$ と指摘されているように、施設体系は制度と不可 分である。従って、制度・施設でない居場所には、施設体系に相当 する枠組みが最初から存在するわけではない。ところがこれらの論 文では、「ここでいう交流の場とは、食事や作品の展示といった中 心となるサービスがある場合でも、誰でも気軽に立ち寄ることがで き、お茶をのみながら世間話をするなど、思い思いに過ごすことが できるような運営や空間設定がされている場のことである」(17、「本 論で言う『高齢者の居場所』とは、行政や NPO、ボランティア団 体などが開設し、高齢者に生涯学習・趣味活動、食事・喫茶、交流・ 情報交換などの機会と場を提供する場所を指すこととする」(24、「外 国人居住者の精神的な拠り所＝居場所（以下、居場所）」(27、「まち の居場所」は「柔軟な運営によって喫茶、趣味の教室、展示をはじ めとした多様な活動を実施することが可能な場所である」(31)という ように、著者は自らが調査対象とする居場所を、どのような機能を 担うかを含めて定義している。つまり、研究を通して調査対象がそ の中に位置づけられるような枠組みが作り出されているのである。 
一方、環境、システムなどのより大きな枠組みに適用するための 知見を得ることを目的とする論文もある。これらの論文における調 査対象と知見の適用対象の関係は、「重要伝統的建造物群保存地区」 を調査対象として「歷史的町並みが日々生活を営む生活空間として 存続する可能性を探るための基礎的知見を得る」 (3)、「知的障害者 入所更生施設」を調査対象として「知的障害者の生活環境の計画に 向けての知見を得る」(11)、子育て支援施設」を調査対象として「今 後の子育て環境のあり方について考察する」 13 、「高齢者の居場所」 を調査対象として「高龄者の地域継続居住支援システムを考えるう えでの一資料を提供する」(44などのようになっている。調査対象と 知見の適用対象における人々の属性が同じ論文が多いが、これらの 論文における知見の適用対象は、調査対象がその中に位置づけられ る枠組みを包含するもので、調査対象をその内に含む枠組みを横断
したり崩したりすることには言及されていない注11)。

$2 つ$ 目は、調査対象から抽出した現象を要素に還元して説明する ことである。例えば、「居住者による居場所選択の要因を、家具な ぞの物理的要素、人間関係などの人的要素、心理的状態や属性など の個人の要素に整理し、考察する」(5)、施設選択理由を『活動意識』、 『人間関係』、『立地・空間』、『管理運営』に 4 分類し、中高生が施 設を選択する際に重視する要因を把握する」(19)のうう、31 編の うち 24 編が論文中に要素や要因の表現を用いている。要素への還 元によって説明されている現象が、論文においてどのように位置づ けられているかに注目すると注 12$) 、 24$ 編のうち 16 編が、夕イトル または研究目的に記載している現象を要素への還元によって説明し ている。つまり、論文において中核的な部分が、要素への還元によっ て説明されているのである (Table 7)。ある現象を要素に還元して

Table 5 Descriptions about generalization of research findings（知見の一般化に関する記述）

\begin{tabular}{|c|c|c|c|c|}
\hline No & $\begin{array}{c}\text { 知見の一般化に関する記述 } \\
\text { (Descriptions about generalization of research findings) }\end{array}$ & $\begin{array}{r}\text { 調査対象 } と \\
\text { (Research objects and Objects to v }\end{array}$ & & $\begin{array}{l}\text { の適用対象 } \\
\text { h research findings will be applied) }\end{array}$ \\
\hline (3) & 「歴史的町並みが日々生活を営む生活空間として存続する可能性を探るための基礎的知見を得る」(p.131) & $\begin{array}{l}\text { 「重要伝統的建造物群保存地 } \\
\text { 区」 }\end{array}$ & $<$ & 「歴史的町並み」 \\
\hline (4) & 「今後の単位制高校の計画に資する」(p.115) & ○「単位制高等学校」 & $\rightarrow$ & 「単位制高校」 \\
\hline (5) & 「GH などの痴呆性高齢者の居住環境やケア環境の構築に関する指針を得る」(p.146) & $\begin{array}{l}\text { 「痴呆性高齢者グループホー } \\
\text { ム」 }\end{array}$ & $<$ & $\begin{array}{l}\text { 「GH などの痴呆性高歯者の } \\
\text { 居住環境やケア環境」 }\end{array}$ \\
\hline (7) & 「今後の屋外ゾーニング計画に向けた整備要件・課題を抽出する」(p.150) & ○「小学校屋外空間」 & $\rightarrow$ & (小学校の)「屋外ゾーニング」 \\
\hline (8) & $\begin{array}{l}\text { 「地域における中高生の居場所のあり方や居場所づくりの手法を、実践的な取り組みの中から導き出して } \\
\text { いきたい (p.50) }\end{array}$ & $\begin{array}{l}\text { ○「児童館」、「中高生対応児 } \\
\text { 童館」(「中高生の居場所づく } \\
\text { に取り組んでいる皆童館」) }\end{array}$ & $\rightarrow$ & $\begin{array}{l}\text { 「地域における中高生の居場 } \\
\text { 所のあり方や居場所づくりの } \\
\text { 手法」 }\end{array}$ \\
\hline (11) & 「知的障害者の生活環境の計画に向けての知見を得る」(p.71) & ○「知的障害者入所更生施設」 & $<$ & 「知的障害者の生活環境」 \\
\hline (13) & 「今後の子育て環境のあり方について考察する」(p.25) & ○「育て支援施設」 & $<$ & 「子育て環境」 \\
\hline (14) & $\begin{array}{l}\text { 「車椅子利用者独特の環境活用方法の特徵を明らかにすることで、生態学的妥当性の観点から今後のユニ } \\
\text { バーサルデザインのあり方を考察する」(p.87) }\end{array}$ & 「自立支援福祉施設」 & $<$ & 「ユニバーサルデザイン」 \\
\hline (16) & 「生活環境としての中学校空間の在り方を考察する」(p.31) & ○中学校」 & $\rightarrow$ & 「中学校」 \\
\hline (17) & 「交流の場の空間や運営、地域の支援体制に関する知見を得る」(p.68) & 「交流の場」 & $\rightarrow$ & 「交流の場」 \\
\hline (18) & 「放課後の居場所づくり」の「計画課題と今後の方向性を求 & $\begin{array}{l}\text { 〔「児童の放課後の居場所づ } \\
\text { くり」 }\end{array}$ & $\rightarrow$ & $\begin{array}{l}\text { 「児童の放課後の居場所づく } \\
\text { り」 }\end{array}$ \\
\hline (19) & 中高生の「「居場所」に求められる成立条件を得る」(p.39) & $\begin{array}{l}\text { 「「公共及び民間施設を利用 } \\
\text { した中高生の「居場所」」 }\end{array}$ & $\rightarrow$ & 中高生の「居場所」 \\
\hline (20) & 「地域の公共施設が人々の居場所になるための計画的要件を得る」(p.1205) & ○「地域の公共施設」 & $\rightarrow$ & 「地域の公共施設」 \\
\hline (21) & 「今後の児童養護施設の建築計画の一助となる」(p.1691) & 「児童養護施設」 & $\rightarrow$ & 「児童養護施設」 \\
\hline (23) & 「今後の小舎化における利点と課題等について明らかにする」(p.2340) & ○「小舎制児童養護施設」 & $\rightarrow$ & (児童養護施設の)「小舎化」 \\
\hline (24) & $\begin{array}{l}\text { 「高齢者の地域継続居住支援システムを考えるうえでの一資料を提供する」(pp.973-974)、「今後の高齢者 } \\
\text { の居場所づくりのための知見を得る」(p.974) }\end{array}$ & 「高歯者の居場所」 & $\underset{\rightarrow}{<}$ & $\begin{array}{l}\text { 「高龄者の地域継続居住支援 } \\
\text { システム」「高歯者の居場所」 }\end{array}$ \\
\hline (27) & $\begin{array}{l}\text { 「外国人居住者の居場所が、セグリゲーションを引き起こすことなく、日本人住民との相互理解を深化さ } \\
\text { せていくための要件を考する」(p.2166) }\end{array}$ & $\begin{array}{l}\text { 「団地内の冊い地及び店舗群」 } \\
(\ulcorner\text { 外国人居住者の居場所」) }\end{array}$ & $\rightarrow$ & 「外国人居住者の居場所」 \\
\hline (30) & 「「居場所施設」のあり方を考察する」(p.56) & $\begin{array}{l}\text { 施設」」不登校中高生の「居場所 } \\
\end{array}$ & $\rightarrow$ & 「居場所施設」 \\
\hline (31) & 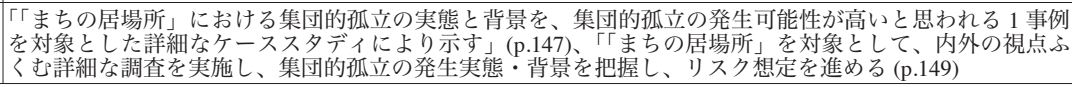 & $\begin{array}{l}\text { 「診療所によって運営されてい } \\
\text { る「まち居場所」」 }\end{array}$ & $\rightarrow$ & 「まちの居場所」 \\
\hline
\end{tabular}

は調査対象が施設であることを表す。

※調查対象と知見の適用対象の関係について、「 $\rightarrow$ は両者が同じ枠組みにある場合、「く」は知見の適用対象が調查対象を包含する場合を表す。

Table 6 Supplementary explanation about research findings（知見に関する補足説明）

\begin{tabular}{|c|c|c|}
\hline No & $\begin{array}{l}\text { まとめ部分における知見に関する補足説明 } \\
\text { (Supplementary explanation about research findings) }\end{array}$ & $\begin{array}{c}\text { 調查タイプ } \\
\text { (Research } \\
\text { Type) }\end{array}$ \\
\hline (3) & $\begin{array}{l}\text { 「くつろげる空間、楽しい空間がない居住者や自宅内にとどまっている居住者を自宅外に向け、空間の選択性を高めることによって、居住地としての魅力は増 } \\
\text { すことが示唆される。(p.138) }\end{array}$ & 大量統計 \\
\hline (4) & $\begin{array}{l}\text { 「単位制高校では双方向の情報伝達を支える携帯電話の利用がさらに進むと考えられるので、その利用を支援する仕組みも必要になると思われる。」(p.121)、本 } \\
\text { 調査は、1993 年と1999年とに行ったアンケート調査をもとにて分析を進めたものであり、詳細に状洗を分析するまでには至っていない。(p.121) }\end{array}$ & 少数精密 \\
\hline (5) & $\begin{array}{l}\text { 「今後この研究を発展させ、他の居住施設においても固有の居場所の形成を促すような建築はどのような要素によつて構成されるのかを具体的に探ることによ } \\
\text { り、居住のための誨設全般にわたる計画の指針が得られるのではないかと考えている。」(p.152) }\end{array}$ & 少数精密 \\
\hline (11) & $\begin{array}{l}\text { 「ユニット内共用空間を固有の居場所としていた入居者の居場所選択の要因は、人的要素に影響を受けており、他者との居合わせの場としての配慮が重要であ } \\
\text { ると思われる。」( } .78)\end{array}$ & 少数精密 \\
\hline (14) & 「本研究では健常者の居場所の選択行動自体は調査対象としていないため、あくまで限定的な知見ではあるが、…‥(p.93) & 少数精密 \\
\hline (16) & 「このようなことから生徒の活動に対応する多様な空間を校内全体に点在させることが望ましいと考える。」(p.36) & 少数精密 \\
\hline (18) & $\begin{array}{l}\text { 「各地域において、地域住民のサポートを得ながら居場所のスタッフ数を増やす等の方法が、ケガ等の危険防止や充実した活動展開の側面からも模索されてお } \\
\text { 、、今後も見守り体制が手厚い場所づくりは増えていくもの考察される」(p.39) }\end{array}$ & 少数精密 \\
\hline (21) & $\begin{array}{l}\text { 「施設形態やケアシステムの変化がなされるときには、そこに住む子供達一人一人の心の動きがあり、新しいことや変化を受け止めていくのに一つ一つ確かめ } \\
\text { ていく時間が必要であり、そのような時、既存施設の改変によつて小規模化する A 園の取り組みは一つのあり方として参になる゙あろう。(p.1697) }\end{array}$ & 少数精密 \\
\hline (23) & 「子ども達の精神的発達のための「一人になれる」空間である「自室」の必要性が推察される。」(pp.2344-2345) & 少数精密 \\
\hline (24) & $\begin{array}{l}\text { 「複数利用の場合の居場所選択要因として、相互の距離やその居場所を通じた人間関係などが類推される。」(p.980)、居場所の利用経験がその後の継続利用の } \\
\text { 意向に結びつく傾向があり、地域継続居住する高龄者に多様な機会を設けることの意義を類推させる。(p.980) }\end{array}$ & 大量統計 \\
\hline (27) & $\begin{array}{l}\text { 「本研究はヒアリング調査への協力が得られた関係者の発言をもとに分析を行っているため、収集できたデー夕から研究上明らかにできる内容には自ずと限界 } \\
\text { がある。」(p.2172) }\end{array}$ & 少数精密 \\
\hline
\end{tabular}


説明することは捨象であるが、捨象であるがゆえに、それぞれにユ ニークな調査対象から得られた知見を一般化することの飛躍を乗り

越える前提にされていると考えることができる。

要素への還元によって説明される現象については、24 編のうち 11 編が選択をあげており、これらを含めて 24 編のうち 18 編が人間・ 環境関係についての現象をあげている。これらの論文の中には、物 理的な要素をはじめとする環境側の要素によって現象を説明してい る論文と、環境側の要素だけでなく、「心理的状態や属性なぞの個 人の要素」(5)、『被受容感』『精神的安定』『行動の自由』『思考・ 内省』『自己肯定感』『他者からの自由』の 6 要因」211など人間側の 要素もふまえて現象を説明している論文がある。

18 編の論文は人間・環境関係についての現象を、主に行動観察
調査により観察された行為として抽出している論文と注 ${ }^{13)}$ 、主にア ンケート調査やインタビュー調査により意識として抽出している 論文に分けることができる。前者が 13 編、後者が 7 編で、このう ち 2 編が両者を併用している。行動観察調査を用いている論文では 様々な現象が抽出されているが、例えば、最も多くあげられている 選択という現象を説明しょうとする 7 編の論文では、「滞在頻度や 滞在時間、その場所での行為に特徴を持つ」(5)、「場所ごとの滞在 時間の合計と行動軌跡」(11、「滞在頻度や滞在時間、その場所での 行為」(12、「行動軌跡・活動の内容や相手・発話の様子」(15)、「滞在 場所、行為内容、集団規模」(16、「関わりの発生場所」(22) ${ }^{\text {i 14) }}$ 、「子 ども達が誰とどこで何をしていたのか」(23)と表現されているょう に、選択するという動きのある行為そのものではなく、その行為の

Table 7 Descriptions about reduction to elements（要素への還元に関する記述）

\begin{tabular}{|c|c|c|c|}
\hline No & $\begin{array}{c}\text { 説明される現象 } \\
\text { (Phenomena explained in the papers) }\end{array}$ & $\begin{array}{c}\text { 人間・環境関係についての現象の抽出に関する記述 } \\
\text { (Descriptions about pheme extraction of people-environment relationship) }\end{array}$ & \\
\hline (1) & ○「場の形成」 & 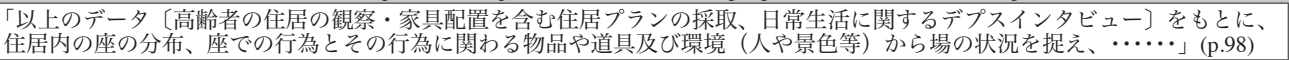 & 観察 \\
\hline (3) & $\begin{array}{l}\text { ○「〈楽しい〉場所」と、その場所に } \\
\text { 交流相」との「関連性」 }\end{array}$ & 「個人票では〈くつろげる・落ち着く〉、〈楽しい〉と意識する場所と相手を 2 番目までたずねており、…... (p.132) & 意識 \\
\hline (5) & ○「固有の居場所の選択」 & 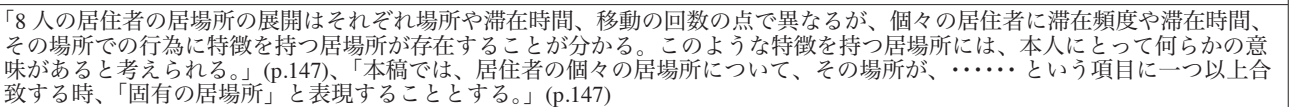 & 観察 \\
\hline (6) & ○「居場所形成」 & 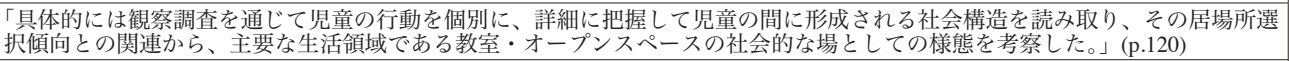 & 観察 \\
\hline (7) & 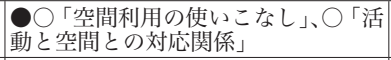 & 「活動時間別〔授業時間、休み時間、放課後・週末〕児童の活動と敷地内屋外空間の使われ方を抽出」(p.150) & 観察 \\
\hline 8 & ○児童館の「中高生対応の方法」 & - & - \\
\hline (9) & $\begin{array}{l}\text { ○「滞在型・移動型活動の展開頻度 } \\
\text { と継続時間およ゙活動か搌開した場 } \\
\text { 所」の関係 }\end{array}$ & 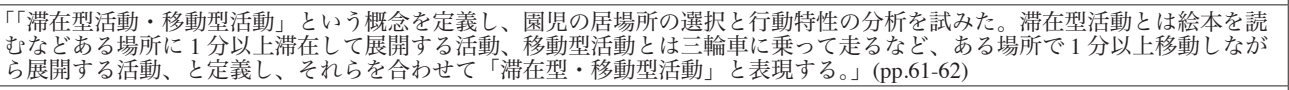 & 観察 \\
\hline (10) & ○「固有の活動場面の成立」 & $\begin{array}{l}\text { 「個人追跡調査の結果から、園児一人ひとりに特徴的な滞在型・移動型活動場面を以下の条件によって抽出し、固有の活動場面 } \\
\text { と定義した。 } .50)\end{array}$ & 観察 \\
\hline (11) & ○「固有の居場所選択」 & 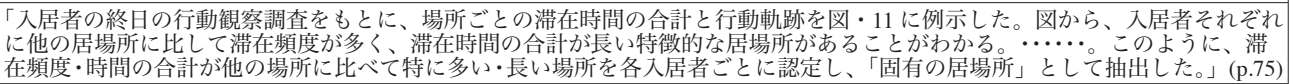 & 筧察 \\
\hline (12) & ○「固有の居場所選択」 & 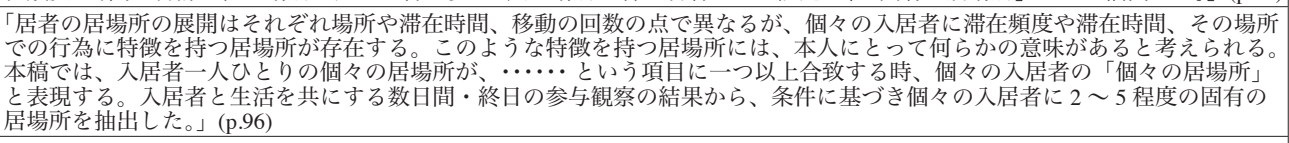 & 観察 \\
\hline (14) & 「空間の特徵」の分類 & - & - \\
\hline (15) & ○「居場所の選択」 & 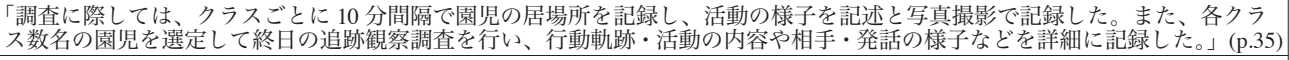 & 観察 \\
\hline (16) & ○「「特別教室や教科教室」の選択 & 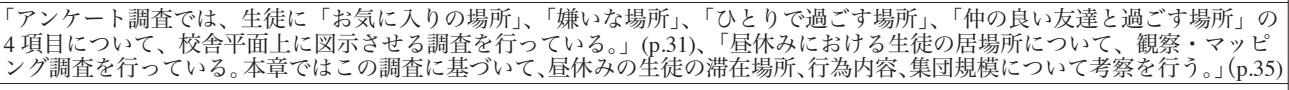 & 雉察 \\
\hline (17) & \begin{tabular}{|l|l|} 
状況の交流の場」の「住宅と店舗での \\
\end{tabular} & - & - \\
\hline (18) & 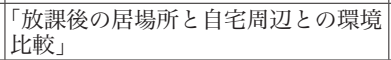 & - & - \\
\hline (19) & ○「施設選択」 & $\begin{array}{l}\Gamma \ldots . . . . \text { 設置建物種の異なる } 6 \text { 件 (公共型 } 3 \text { 件、民間型 } 3 \text { 件）及び広域型 } 2 \text { 件の利用者を対象に、利用状況や利用意識に関す } \\
\text { るアンド }\end{array}$ & 意識 \\
\hline (20) & ○「居場所の選択」 & 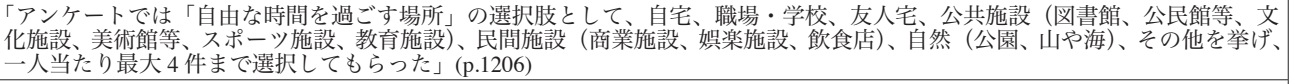 & 意識 \\
\hline (21) & ○「「居場所」選択」 & 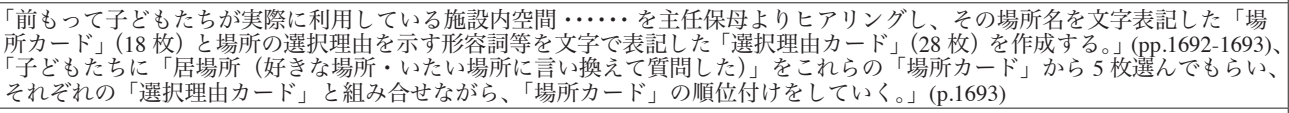 & 意識 \\
\hline (22) & ○「居場所選択」 & 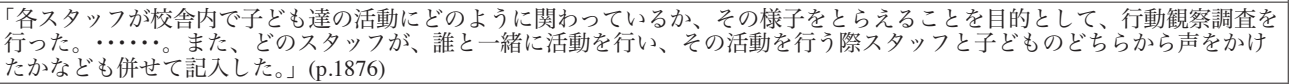 & 観察 \\
\hline (23) & $\begin{array}{l}\text { ）「自室の選択理由」○「交流の場 } \\
\text { の選択」 }\end{array}$ & 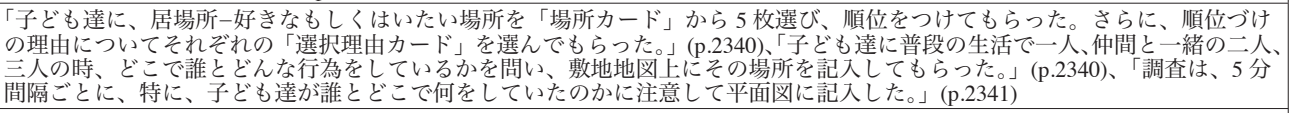 & 観察 \\
\hline (24) & ○「居場所選択」 & $\begin{array}{l}\text { 「調査当日に居場所を訪孔た利用者が地域の居場所を相互にどの様に利用しているのかを把握するため、各居場所において他に } \\
\text { 利用している場所を複数回答で筫問した。」( } .978)\end{array}$ & 意識 \\
\hline (27) & $\begin{array}{l}\text { @「団地の店舗群」(外国人居住者の } \\
\text { 居場所) の撤去 }\end{array}$ & - & - \\
\hline (29) & ○「他者に開か扎た交流空間」の開設 & - & - \\
\hline (30) & ○「「場」と「居場所」の評価」 & 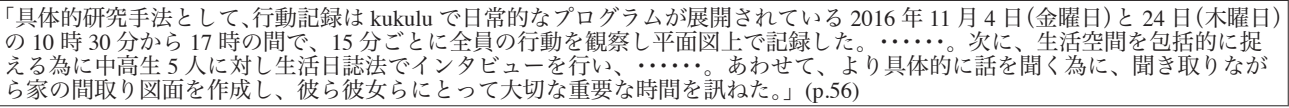 & 観察 \\
\hline
\end{tabular}


結果としての位置、及び、位置の集積が抽出されていることがわ かる。一方、意識を抽出している 7 編の論文の中には、「くくつろ゙ る・落ち着く〉、〈楽しい〉と意識する場所と相手」（3、「自由な時 間を過ごす場所」20、「好きな場所・いたい場所」21、「好きなもし くはいたい場所」(23のように、著者が居場所と定義するもの（Table 2）についての意識を抽出する論文と、(19)24のように著者が居場所 になり得ると考えている施設や場所についての意識を抽出する論文 がある。いずれも居場所そのものに関わっているがゆえに、「くく ろげる・落ち着く〉は住宅に求められる基本的機能であり、〈楽しい〉 はより積極的な生活の要求として位置づけられ」(3)、「子ども達の 社会化にとって居場所があることは、重要な要素である」(23)どの 表現に表的ているように、抽出されているのは著者が必要と考える ものである。また、意識を抽出している論文の中で191201、調査対 象に関わる人々のニーズを把握しょうとする論文である（Table4）。 このように、ここで抽出されている意識とは、調査対象者にとって のニーズ、または、著者がニーズだと考えるものに関わっている。

\section{6. まとめと考察}

\section{6-1. 居場所の制度化と建築計画学における事例研究}

本稿では、１］居場所の制度化がどのようなプロセスなのか、そ して、[2] 建築計画学における事例研究はこのプロセスにどのよう に関わってくるのかを考察した。本稿の考察から以下を見出すこと ができた。

［1］居場所の制度化

『日本建築学会計画系論文集』においては、1990 年代後半から継 続的に居場所をタイトルに用いる論文が刊行されてきた。居場所を タイトルに用いる 31 編のうち 22 編が施設を調査対象としている。 居場所は当初、制度・施設でないものを意味していたが、建築計画 学論文では居場所を施設との関わりで捉えているものが多い。

本稿では既往研究の議論をふまえ、居場所では、機能は生じてく る要求にその場所で対応することで事後的に備わってくるのに対し て、施設では、機能は要求に先行して実現すべきものとしてあらか じめ設定されると捉えた。そして、居場所の制度化を「要求一機能」 関係が反転するプロセスと捉えた。

31 編のうち、居場所の定義を明記している論文は 19 編である。 19 編のうち、居場所を制度・施設でない場所として定義している のは 2 編であった。残りの 17 編は居場所を行為、及び、精神的・ 心理的な側面から定義していたが、これらの論文の中には居場所を 何らかの状態を可能にするものとして定義している論文があった。 佐々木嘉彦は「目的達成（=欲求充足）において物がはたす（ある いは期待されている）役割（=働き）を機能」と捉えていたが ${ }^{12)}$ 、 この議論をふまえれば、何らかの状態を可能にするものは機能と捉 えることができる。注目すべきは、調査対象が居場所と表現されて いるものの、研究者がそれを施設と捉えている 4 編のうち 3 編が、 居場所を機能と定義していることである。居場所の制度化のプロセ スにおける「要求一機能」関係の反転は、これらの論文における居 場所の定義にも現れていると考えることができる。

[2] 建築計画学における事例研究と「要求一機能」関係の反転

本稿の考察より、建築計画学における事例研究は、居場所の制度 化、つまり、要求一機能」関係の反転のプロセスに次のように関わつ
ていることを見出すことができた。

建築計画学論文は様々な課題に注目しており、その課題を考察す るために調査対象を選定している。これらの論文においては社会の 状況や既往研究などをふまえて、研究者が望ましいと考える状態か ら何かが欠如している状態が課題として設定され、調査対象はその 欠如を埋める手がかりとされているのである。一般的に社会的弱者 とみなされる属性の人を対象とする論文も多い。社会的弱者とは成 人（健常者である成人男性）から何らかの属性が欠如した存在であ るという捉え方が許されるならば、社会的弱者を対象とすることも また欠如への注目だと言える。

欠如を埋めるために焦点があてられているのがニーズであり、研 究者が調查対象に関わる人々のニーズを把握しようとする論文があ る。また、研究者があらかじめ調査対象やそこに関わる人々に対し てニーズを提示している論文もあり、中には居場所自体をニーズと して提示している論文もある。居場所においては、機能は生じてく る要求にその場所で対応することで事後的に備わってくる。従っ て、居場所の機能は要求に応じて、場合によっては想定しないかた ちで多様になっていく可能性がある。ところが、研究者が何らかの 欠如に注目し、調査対象をその欠如を埋め合わせる手がかりとして 位置づけることは、多様な可能性の中から、あらかじめある特定の 機能に焦点をあてることになる。また、研究者が人々のニーズを把 握したり、ニーズを提示したりすることは、第三者としての研究者 による要求の先取りとなる。これらは、「先に要求がありそれに対 して機能が発生する、という本来の『要求一機能』関係」12) を反 転させるものである。

研究目的に関しては、多くの建築計画学論文が知見の一般化を目 的に揭げている。知見の一般化においては、「今後の」、計画」と いう表現に典型的なように、研究が行われる時点では知見の適用対 象はまだ存在しないことが前提とされている。従って当然ながら固 有名のある人々による要求自体が存在していない。これもまた、要 求一機能」関係の反転に関わってくる。

知見の一般化に関して、特に「少数精密調査」を行う論文におい ては、それぞれにユニークである調査対象から得られた知見が、な ぜ一般に適用できるのかが必ずしも明確に議論されておらず、議論 の展開に飛躍がみられる。建築計画学論文がどのようにこの飛躍を 乗り越えようとしているかに注目すると、調査対象をある柲組みの 中に位置づけること䑭 ${ }^{15)}$ 、そして、調査対象における現象を要素に 還元して説明することが、この飛躍を乗り越えるための前提になつ ていると考えることができる注 16$)$ 。枠組みは制度と不可分であるた め、制度・施設ではない居場所には、最初から施設のような朹組み が存在するわけではない。ところが、研究の過程で研究者は、自ら が調査対象とする居場所を、ぞのような機能を担うのかを含めて定 義している。これによって、調査対象がその中に位置づけられるよ うな枠組みが作り出されており、居場所があたかも施設のようなも のとして取り扱われている。

要素への還元によって説明されているのは、人間・環境関係につ いての現象が多い。これらの論文は人間・環境関係についての現象 を、観察された行為として抽出する論文と、意識として抽出する論 文に分けることができる。後者で意識として抽出されているのは、 調査対象者のニーズに関わるものであった。これも先に述べた第三 
者としての研究者による要求の先取りであり、「要求一機能」関係 の反転につながる。一方、前者の観察された行為の抽出については、 これを考察するために、改めて佐々木嘉彦の議論に注目したい。

佐々木嘉彦は「人一物」関係について、「人一物』関係として の行為を人からみれば要求であり、物からみれば機能である。した がって、行為が安定的に持続されている場合には、要求＝機能とな り、これを区別することはでき」ないこと、「人間生活における『人 一物』関係＝行為の様式は、一般にはそう目まぐるしく変化するも のではなく、それが観察されるときは、行為は一応の安定的状態を 保っているのがふつうである」ことを指摘している。ここから佐々 木嘉彦は、要求と機能を分離し、その関係を分析するために「不適 合な状態 $($ 矛盾)」つまり、「まず『人の要求』が変わり、物の機能』 との間に不適合な状態 (矛盾) が生ずる。そこでこの不適合を克服 するために『物』(=機能) が変わって、再び結合が安定的となる」 という「動態」に注目する ${ }^{12)}$ 。

佐々木嘉彦の議論、及び、建築計画学論文において抽出される選 択という現象が、選択するという動きではなく、行為の結果として の位置、及び、位置の集積であったことをふまえれば、居場所に関 して観察されている現象は「一応の安定的状態を保っている」もの だと捉えることができる。この場合、「人一物」関係における要求 と機能は「要求＝機能」として区別できない。この状態にある人間・ 環境関係を、環境側の要素によって説明したり、環境側と人間側の 両方の要素によって説明したりすることは注 17)、「要求＝機能」と して区別できない両者を分解する操作になる。けれども、「物の機 能は固定的であるのではなく、要求のちがいや変化に対応して異な る」のであったから ${ }^{12)}$ 、この切り離しによって得られた要求と機 能は、「先に要求がありそれに対して機能が発生する、という本来 の『要求一機能』関係」 ${ }^{13)}$ を反転させることにもなり得るのである。

\section{6-2. 建築計画学における事例研究の社会的意味}

建築計画学における事例研究は、その成果が制度に取り込まれる 傾向を有すると指摘されていたが、以下の指摘をふまえれば、本稿 の考察により見出した欠如への注目が、建築計画学と社会との接点 として大きな意味をもつてきたと考えることができる。

松村秀一は、「20世紀の日本での建設行為」は「ないから建てたい」 という「集団的な動機」に支えられていたのに対して、「ストック が充足した 21 世紀の日本」における集団的な動機は「あるけど何 とかしたい」という類のものに変わると指摘する ${ }^{16)}$ 。この議論を 受ければ、欠如への注目とは、20世紀の日本の「ないから建てたい」 という「集団的な動機」に対応して、建築計画学が担った役割だと 捉えることができ、これが居場所に注目する建築計画学論文にも継 承されていると捉えることができる。

佐藤航陽は、社会システムは「血縁型の封建社会」「ハブ型の近 代社会」「分散型の現代社会」と変遷してきたと指摘する ${ }^{17)}$ 。こ のうち、「ハブ型の近代社会」は「誰もが同じ情報を容易に共有で きない」という「情報の非対称性」が前提となって作られたシステ ムで、「どこか一カ所に中心をつくり、そこに情報を集めて誰かが 代わりに指示を出す形が、最も効率的なアプローチ」となる。結果 として、中心にあって情報のハブの役割を担う「代理人」が大きな 力を有することになる。調査対象から得られた知見を一般化しょう とする研究者とは、「ハブ型の近代社会」おいて情報のハブの役割
を担う「代理人」である。そして、「ハブ型の近代社会」の前提と なる「情報の非対称性」とは、研究者と調査対象者、多くの論文で は社会的弱者と見なされる人々、との間に垣間見ることができる。

山本哲士は、イバン・イリイチが学校、医療、モーター輸送を例 にあげて、これらの制度（産業サービス制度）により学ぶ、癒す、 歩くという自律行為が麻㽻させられること、そして、「産業サービ 又制度を産みだし、それを維持しているのが専門家集団である」こ とを指摘していることをふまえて、次のように指摘している。「教 育が足らない、医療が足らない、速度がエネルギーが足らないとい う、久如がその充足をめざす経済世界を構成していく。そして、欠 如を埋めていくのが、制度化であり、これをわたしは『制度生産様 式』と設定している。…‥その上で、『欠如』は『稀少なもの』 へと転じられていくのである」「稀少性の世界がつくりだされる と、専門家によって稀少と定義された商品のみが、人々の必要を満 たすものとなっていく」 ${ }^{18)}$ 。欠如への注目という問題意識からはじ まる建築計画学論文は、制度（産業サービス制度）を産みだし、維 持してきた専門家集団の役割と重なっている。そして、「要求一機 能」関係の反転によって生じる居場所の制度化とは、居場所が「専 門家によって稀少と定義された商品」とされ、その稀少性から人々 のニーズが生み出されてくるプロセスである。

このように、久如への注目は建築計画学と社会との接点になって おり、本稿でみたように、これが居場所の制度化としての「要求一 機能」関係の反転のプロセスを生み出す契機となっていた。ところ が、子どもの居場所、コミュニティカフェや地域の茶の間、そして、 こども食堂など様々な領域から居場所の制度化に対する問題提起が なされていることは、社会における「集団的な動機」が変容しつつ あることの現れだと捉えることができる。それでは、機能が要求に 先行してあらかじめ設定される施設ではなく、生じてくる要求への 対応として事後的に機能が備わってくる居場所を計画するとは何を 意味するのか、これに対して建築計画学はどう寄与できるのか。

佐々木嘉彦は要求と機能の関係を分析するために「不適合な状 態」に注目していたが ${ }^{12)}$ 、建築計画学において欠如への注目が大 きな意味をもってきたとすれば、「不適合な状態」もまた欠如とし て扱われる可能性を否定できない注 ${ }^{18)}$ 。本稿に扮ける議論より、「要 求=機能」として両者が区別されない「行為が安定的に持続されて いる」ことに注目して、居場所についての議論を展開することが今

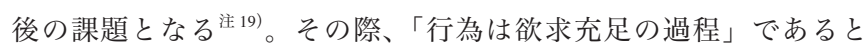
いう佐々木嘉彦の議論をふまえれば、「行為が安定的に持続されて いる」ことそれ自体が要求の充足と不可分なのであり、その行為を 先取りされた何らかのニーズのための手段として捉えないという観 点が必要になる。また、要素への還元のために抽出されていた選択 という現象が、選択するという行為ではなく、その結果としての位 置、及び、位置の集積であったことをふまえれば、「行為が安定的 に持続されている」ことを位置や位置の集積でなく、行為そのもの として捉えるという観点も必要になる。

\section{謝辞}

本稿の執筆においては、大阪大学の舟橋國男名誉教授から貴重な ご意見をいただきました。心より感謝申し上げます。 
注 1）五十嵐太郎が、「日本語では別々の単語だが、英語の『インスティテュー ション』という言葉は『制度』と『施設』の両方の意味をもつ。ある施設が 成立するということは、それを支える制度が確立しているということだ。福 祉施設というように、制度が機能している状沉を含めて、はじめて施設とい う言葉は生きている。一ヶ所しか存在しえない特殊な建物は施設と呼ばない」 と指摘するように（文献 1)、制度と施設は不可分のものである。

注 2）電子ジャーナルの公開システム「J-STAGE」で、論文タイトル：居場 所」「資料夕イトル:日本建築学会計画系論文集」の条件で検索したところ、 2019 年末までに刊行された論文として 34 編がヒットした。このうち、海外 の事例を扱う 2 編と実験調査を行う 1 編を除く 31 編が本稿の対象である。

注 3）この最終報告書は、居場所の語を初めて用いた行政文書である。

注 4）居場所と施設の違いが「要求一機能」関係のあり方であることは、機能 の観点からは両者を完全に分離できないことを意味する。

注 5）「疾呆性高歯者ケアの切り札として、痴呆性高齢者グループホーム（以下： GH）が 1995 年前後に日本に紹介された。GH は 2000 年施行の介護保険で 制度の一つに採用され、急速に増加している」(12) と指摘されているように、 元々、日本に存在しなかった痴呆性高龄者グループホーム $(\mathrm{GH}) も$ 制度に 取り込まれていったのである。

注 6）(3)と(30は行為、精神的・心理的の両方の側面から定義している。また、 痴呆性高齢者グループホームを調査対象とする(5)と(12)物理的要素、人的要 素、心理的要素、個人的要素を含む概念として居場所を定義しているが、こ れらの論文では滞在や選択、あるいは、「その場所と結びついた行為や発話 がある」という行為の側面から「固有の居場所」を捉えているため、ここで は行為の側面から居場所を定義している論文に分類している。

注 7）ここで議論しているのは問題意識であり、研究の結果として見出された 課題ではない。また、ある観点からの研究が十分でない、行われていないと いう研究上の課題のことでもない。

注 8）ここでは、各論文において「本研究は〜を目的とする」などのように記 載されている部分の内容を取りあげている。

注 9）「大量統計調査」と「少数精密調査」の分類は門内輝行（文献 14）によ る。両夕イプを併用しているのは(8)で、前半で「大量統計調査」として全国 の 583 ケ所の児童館の調査を行い、後半で「少数精密調査」として 4 ヶ所の 中高生対応館の調査を行っている。

注 10）このような記述は「大量統計調査」を行う論文にもみられる。

注 11）例元ば、「自立支援福祉施設」から得られた知見を「子育て環境のあり方」 に適用するというょうに、属性の異なる人々に適用するための知見を得るこ とも考えることができるが、ここで注目している論文においてはこのような 目的は掲げられていない。枠組みを横断したり崩したりすることに言及され ていないとはこのような意味である。

注 12）要素への還元によって説明されている現象は、それぞれの論文において 要素や要因という表現が用いられている部分から読及取っている。

注 13）行動観察調查によって抽出した現象を説明するために、インタビュー調 查、アンケート調査などを併用している論文もある。

注 14）「関わりの発生場所」22の表現は、現象の抽出に関する部分（Table 7） にはみられないが、(22)の第6 章のタイトルに用いられている表現である。

注 15）それぞれにユニークな場所を居場所と捉えることも枠組みの中への位置 づけであり、そ扎亲、本稿もこのことと無縁ではない。それゆ充、「要求 一機能」関係には意識的である必要があると考えている。

注 16) 本稿における議論に関連して、長澤泰らは従来の建築計画学に対して、「分 析的・要素還元型からの脱却」「不特定多数＝群集へに対する一般化から個 別化へ」「利用者の行為レベルでの『要求』の拾い上げや政治・仕組みの代 弁ではなく、利用者の何を代弁するのかを考察する態度」などの立場や考元 方をもつ建築地理学を提唱している(文献 2)。

注 17）舟橋國男は人間・環境関係を理解する視点として、環境決定論、相互作 用論 (インタラクショナリズム)、トランザクショナリズムの3つをあげて いる(文献 15)。ここで言及している、環境側の要素による説明は環境決定論、 環境側と人間側の要素による説明は相互作用論の視点に立つものである。な お、後者は「人の内的なものと外的社会的環境的要因の相互作用という見方 を採り、人と環境との 2 元論を受け入れている」(文献 15$)$ ことから、人間 と環境を一元論的に捉えるトランザクショナリズムではない。

注18）佐々木嘉彦は要求と機能との矛盾関係における現象として、「生活主体 の身体的徴候」「行為間の相互妨害」「矛盾をカバーする行為」の 3 つを挙 げている(文献 12)。

注 19）この状態に注目することは、人間と環境を一元論的に捉えるトランザク ショナリズム（文献 15）に関わってくる。

\section{参考文献}

1) Igarashi, T: Building Type toha Douiumonoka, Igarashi, T. and Ohkawa, N.: Building Type no Kaibougaku, Okokusha, 2010 (in Japanese) 五十嵐太郎: ビルディングタイプとはどういうものか, 五十嵐太郎, 大川信 行編 : ビルディングタイプの解剖学, 王国社 , 2010

2) Nagasawa, Y.: Kenchikukeikakugaku no Keifu, Nagasawa, Y et al.: Kenchiku Chirigaku, University of Tokyo Press, 2007 (in Japanese) 長澤泰 : 建築計画学の系譜, 長澤泰ほか 2 名編 : 建築地理学, 東京大学出版 会, 2007

3) Ohara, K. and Sato, M.: Zuhyo Koureisha notameno Kenchiku-Kenkyu, Journal of architecture and building science, Vol.118, No.1510, pp.22-23, 2003.10 (in Japanese) 大原一興, 佐藤真衣子 : 図表 高齢者のための建築・研究, 建築雑誌, Vol.118, No.1510, pp.22-23, 2003.10

4) Hagiwara, K.: Ibasho, Shunpusha, 2018 (in Japanese) 萩原健次郎 : 居場所一生の回復と充溢のトポス, 春風社, 2018

5) Hisada, K.: Kodomo to Wakamono no Ibasho, Hisada, K.: Kodomo to Wakamono no Ibasho, Hobunsha, 2000 (in Japanese)

久田邦明 : 子どもと若者の居場所, 久田邦明編 : 子どもと若者の居場所, 萌 文社, 2000

6) Takurosho-Grouphome Zenkoku Network: Series Juuminshutai no Service Manual 7 Takurosho, Zenkoku Shakaifukusi Kyogikai, 2016 (in Japanese) 宅老所・グループホーム全国ネットワーク編 : シリーズ 住民主体のサービ スマニュアル 第 7 巻宅老所, 全国社会福祉協議会, 2016

7) Tanaka, Y.: Machi no Ibasho Shisetsu dehanaku, Suiyosha, 2019 (in Japanese) 田中康裕：まちの居場所、施設ではなく。, 水曜社 , 2019

8) Yuasa, M.: “Nantokasuru” Kodomo no Hinkon, Kadokawa Future Publishing, 2017 (in Japanese)

湯浅誠:「なんとかする」子どもの貧困, 角川書店, 2017

9) Tanaka, H.: Kodomo-Wakamono no Henyou to Shakaikyouiku no Kadai, Tanaka, H. Kodomo-Wakamono no Ibasho no Kousou, Gakuyoshobou, 2001 (in Japanese) 田中治彦: 子ども・若者の変容と社会教育の課題, 田中治彦編集 : 子ども・ 若者の居場所の構想, 学陽書房, 2001

10) Sawayakafukushizaidan: Series Juuminshutai no Service Manual 3 Ibasho-Salon Zukuri, Zenkoku Shakaifukusi Kyogikai, 2016 (in Japanese) さわやか福祉財団編 : シリーズ 住民主体のサービスマニュアル 第 3 巻 居場 所・サロンづくり,全国社会福祉協議会, 2016

11) Tanaka, Y.: Ibasho to Shisetsu, Dachikenzemi: A Festschrift for the Centennial of Adachi Sensei' s Birth, DesignEgg, 2019 (in Japanese) 田中康裕 : 居場所と施設, ダチケンゼミ編 : 足立孝先生生誕百周年記念論文 集, デザインエッグ社 , 2019

12) Sasaki, Y.: Seikatsukagaku nitsuite, Seikatsugaku, 1, Domesushuppan, 1975 (in Japanese)

佐々木嘉彦: 生活科学について, 生活学, 第一冊, ドメス出版, 1975

13) Ohara, K: Process to Seido no Design, Ima Aratamete Process Design, AIJ, pp.2638, 2007 (in Japanese)

大原一興 : プロセスと制度のデザイン ,いま、あらためてプロセス・デザイ ン, 日本建築学会, pp.26-38, 2007

14) Monnai, T.: Chousa no Houhou nitsuite, AIJ: Survey and Analysis Methods for Architecture and Urban Planning (Revised Edition), Inoue Shoin, 2012 (in Japanese)

門内輝行 : 調査の方法について, 日本建築学会編 : 建築・都市計画のための 調査・分析方法 [改訂版], 井上書院, 2012

15) Funahashi, K.: Transactionalism to Kenchikukeikakugaku, Funahashi, K.: Kenchiku Keikaku Tokuhon, Osaka University Press, 2004 (in Japanese) 舟橋國男 : トランザクショナリズムと建築計画学, 舟橋國男編 : 建築計画読 本, 大阪大学出版会, 2004

16) Matsumura, S.: Tenkanki yueni Hirogaru Kenkyuryouiki to Kyouka subeki Tougougata Kenkyu, Juutaku no "Kachi” toha Nanika, AIJ, 2009 (in Japanese) 松村秀一: 転換期ゆえに拡がる研究領域と強化すべき統合型研究, 住宅の 「価值」とは何か,日本建築学会, 2009

17) Sato, K.: Mirai ni Sakimawari suru Shikouhou, Discover21, 2015 (in Japanese) 佐藤航陽 : 未来に先回りする思考法 , ディスカヴァー・トゥエンティワン, 2015

18) Yamamoto, T.: Ivan Illich, EHESC, 2009 (in Japanese) 山本哲士 : イバン・イリイチ, 文化科学高等研究院出版局, 2009 


\author{
Yasuhiro TANAKA*1 \\ ${ }^{* 1}$ Freelance, Dr.Eng.
}

"Ibasho" is a Japanese word combining "i"(being) and "basho"(place) and was originally used to describe a physical location. Since the 1980s, non-institutional places with keywords such as "ibasho," including "takurosho," "community cafes," and "kodomo shokudo" opened simultaneously around Japan. Afterward, some of these non-institutional places were institutionalized, used as models for institutions or incorporated into institutions. However, a question arises as to how ibasho, that is, non-institutional places, can be institutionalized. Therefore, this paper discusses the institutionalization process of non-institutional places and case studies in architectural planning research involved in this process.

Referring to previous studies, the fundamental difference between non-institutional places and institutions is taken as follows. Namely, the function of ibasho will be prepared in response to people's demands. Contrary, functions of institutions are predetermined in advance of people's demands. "demand-function" relationship is inverted between ibasho and institutions. Therefore, it is possible to consider the institutionalization of non-institutional places from the perspective of the inversion of "demand-function" relationship.

Materials analyzed in this paper are 31 papers published in the "Journal of Architecture, Planning and Environmental Engineering" with "ibasho" in the title between 1997 and 2019. I consider the methodologies of these papers.

Ibasho initially meant a non-institutional place, but many of these papers considered ibasho to be associated with institutions. By focusing on the critical subjects and the research aims of these 31 papers, this paper found the following disputable issues such as (a)inversion of "demandfunction" relationship, namely, regarding the places studied as means to fill the scarcities, and (b)generalizing research findings from the case studies.

Twenty of the 31 papers focused on various scarcities, and target places were selected to solve the scarcities of which were supposed by researchers. In some of these papers, researchers try to grasp people's needs or suggest needs to people before starting the research to fill in the scarcities. This is the preemption of people's demands by others, thus leading to the inversion of "demand-function" relationship, where functions should be prepared by responding to people's demands.

Nineteen of the 31 papers aim to generalize research findings, but none of them explain why research findings from a limited number of case studies can be generalized, and this makes a leap in logic. One strategy employed to overcome this leap is to situate the places studied in certain existing frames. The frames referred to here are the building types of institutions, but ibasho can not have such frames, because of being a noninstitutional place. In some of these studies, researchers define ibasho as their study objects from the viewpoint of functions and situate them in certain existing frames, thus treating them like institutions. Another strategy employed to overcome this leap is to reduce the phenomena found in their research objects to some physical and/or psychological elements and interpret them. In papers that aim to generalize research findings, it is implicitly assumed that the research findings can be applied to institutions or places that have not yet existed. The fact that institutions or places have not yet existed means that people who supposedly demand something can not be, is also leading to the inversion of "demand-function" relationship.

Through these methodologies, architectural planning research leads to the inversion of "demand-function" relationship. The accumulation of knowledge that inverts "demand-function" relationship will be useful for institutionalizing ibasho. 